\title{
Selective Impairment of Slow Axonal Transport after Optic Nerve Injury in Adult Rats
}

\author{
L. McKerracher, M. Vidal-Sanz, C. Essagian, and A. J. Aguayo \\ Center for Research in Neuroscience, Montreal General Hospital Research Institute and McGill University, Montreal, \\ Quebec, Canada H3G 1A4
}

To investigate cellular responses of injured mammalian CNS neurons, we examined the slow transport of cytoskeletal proteins in rat retinal ganglion cell (RGC) axons within the ocular stump of optic nerves that were crushed intracranially. RGC proteins were labeled by an intravitreal injection of ${ }^{35} \mathrm{~S}$-methionine, and optic nerves were examined by SDS PAGE at different times after injury. In one group of rats, the RGC proteins were labeled 1 week after crushing. From 14 to $67 \mathrm{~d}$ after axotomy, the labeling of tubulin and neurofilaments was reduced in relation to other labeled proteins and to the labeling of tubulin and neurofilaments in the intact optic nerve of controls. To determine whether this reduction in labeling was due to an alteration in axonal transport after axotomy, we prelabeled RGC proteins 1 week before crushing. In such experiments, the rate of slow axonal transport of tubulin and neurofilaments decreased approximately 10fold from 6 to $60 \mathrm{~d}$ after injury. Our results cannot be due only to the retrograde degeneration of RGCs and injured axons caused by axotomy in the optic nerve, because fast axonal protein transport and the fluorescent labeling of many axons were preserved in the ocular stumps of these optic nerves. This selective failure of the slow axonal transport of tubulin and neurofilaments may affect the renewal of the cytoskeleton and contribute to the gradual degeneration of RGCs that is observed after axotomy. The alterations in slow transport we document here differ from the enhanced rates we previously reported when injured RGC axons regenerated along peripheral nerve segments grafted to the ocular stump of transected optic nerves (McKerracher et al., 1990).

The axonal transport of cytoskeletal proteins is essential to the renewal of the cytoplasmic matrix of normal and growing axons. In regenerating peripheral nerves, the requirement for cytoskeletal proteins is increased following axonal interruption, as judged by an enhanced tubulin synthesis and the augmented rate of tubulin transport that accompanies regeneration (Hoffman et al., 1985; Hoffman and Cleveland, 1988; Tetzlaff et al.,

Received Dec. 20, 1989; revised Mar. 23, 1990; accepted Apr. 20, 1990.

This work was supported by MRC postdoctoral fellowships to L.M. and M.V.-S., the Luis Manuel Foundation grant to M.V.-S., and grants from the Medical Research Council of Canada, the Spinal Cord Research Foundation (USA), the Multiple Sclerosis Society of Canada, the Daniel Heumann Fund for Spinal Cord Research, and the Wiesberg Fund to A.J.A. We thank Jane Trecarten for her help with the photography.

Correspondence should be addressed to Dr. L. McKerracher, Montreal General Hospital Research Institute, 1650 Cedar Avenue, Montreal, Quebec, Canada H3G 1 A4.

Copyright (C) 1990 Society for Neuroscience $0270-6474 / 90 / 082834-08 \$ 03.00 / 0$
1988; Miller et al., 1989). In contrast to the successful regrowth of peripheral nerves, cut axons do not normally regenerate in the CNS of adult mammals. Moreover, a retrograde degeneration of axons and cells often follows the interruption of such axons (Allcutt et al., 1984; Misantone et al., 1984; VillcgasPérez et al., 1988, 1989; Sievers et al., 1989).

Studies in adult rodents have shown, however, that certain CNS neurons, such as the retinal ganglion cells (RGCs) of rats and hamsters, are intrinsically capable of axonal regeneration. The expression of the regenerative capacities of these CNS neurons is influenced by components of the non-neuronal environment. In such animals, when a peripheral nerve is grafted as a substitute for the CNS glia of the optic nerve, RGC axons can regrow several centimeters and form well-differentiated functional synapses with neurons in the tectum (Vidal-Sanz et al., 1987; Carter et al., 1989; Keirstead et al., 1989). Furthermore, when the severed RGC axons regenerate along the peripheral nerve grafts, a 2-fold increase in the rate of slow axonal transport of tubulin and neurofilament (NF) proteins has been documented (McKerracher et al., 1990). An increase in the rate of tubulin transport also accompanies the regencration of mammalian peripheral nerves and the regrowth of axons in the optic nerve of amphibia and fish, where axonal regeneration is the rule (Hoffman et al., 1985; Grafstein, 1986). These findings suggest that there are analogies between certain growth-associated changes in cytoskeletal transport in peripheral and CNS neurons of both mammals and nonmammalian vertebrates.

In the present study, we have investigated in adult rats the slow axonal transport of cytoskeletal proteins in the ocular stump of optic nerves that have been crushed intracranially. We report here that the axotomized, nonregenerating RGCs exhibit a marked, selective, and persistent impairment of tubulin and NF transport. The transport of these proteins virtually stops 1 week after injury, while fast axonal transport continues. Thus, many RGC axons that survive within the optic nerve may be unable to renew appropriately components of their cytoskeleton. We suggest that the progressive loss of axons and RGCs obscrved after intracranial axotomy (Richardson et al., 1982; VillegasPerez et al., 1988, 1989) may be influenced by such selective failure of axonal transport.

\section{Materials and Methods}

Optic nerve injury. The optic nerve was interrupted intracranially to obtain a long ocular segment useful for axonal transport measurements. Adult female Sprague-Dawley rats $(180-220 \mathrm{gm})$ were anesthetized by intraperitoneal injection of chloral hydrate $(0.42 \mathrm{mg} / \mathrm{gm}$ body weight $)$, and the left optic nerve was exposed intracranially by aspirating a portion of the left frontal lobe. The RGC axons were severed just in front 
of the chiasma, approximately $9 \mathrm{~mm}$ from the posterior pole of the by repeatedly crushing the optic nerve with fine forceps. At various times after injury, the animals were killed by an overdose of anesthetic, then perfused with $9 \%$ saline before dissecting the tissue.

Radiolabeling of axonal proteins. With the animals under chloral hydrate anesthesia, the RGC proteins were radiolabeled by an intraocular injection of $250 \mu \mathrm{Ci}$ of ${ }^{35} \mathrm{~S}$-methionine (ICN, Irvine, CA) in $5 \mu \mathrm{l}$ saline. Two different procedures were used to label the proteins within the optic nerve (Fig. 1). In the first set of experiments (Fig. 1a), the left optic nerve was crushed $7 \mathrm{~d}$ prior to labeling. The left optic nerve and right optic tract were removed 7 ( $n=2$ animals), $10(n=1), 16(n=$ 2), $30(n=3)$, and $60(n=2) \mathrm{d}$ after labeling, cut into 3 -mm segments, and processed for SDS gel electrophoresis. Control animals were injected at the same time, but their optic nerves were not crushed. The animals were killed at $7(n=2), 10(n=2), 16(n=2), 30(n=4)$, and $60(n$ $=3$ ) days after injection.

In the second series of experiments (Fig. $1 b$ ), proteins in the RGC axons were prelabeled prior to crushing the optic nerve. Both eyes were injected with $250 \mu \mathrm{Ci}{ }^{35} \mathrm{~S}$-methionine. Six days later, when the tubulin and NF proteins had just entered the optic nerve (see Fig. 3), the left optic nerve was crushed intracranially as described above. The contralateral right optic nerve of the same animal was used as a control. Four $(n=3), 6(n=3), 8(n=5), 11(n=2), 30(n=2)$, and $60(n=3) \mathrm{d}$ after the optic nerves were crushed, the animals were killed and both optic nerves were removed, cut into $2-\mathrm{mm}$ segments, and processed for SDS gel electrophoresis. The same procedure was followed in another set of experiments, but in these, the optic nerve was crushed $20 \mathrm{~d}$ after labeling $(n=4)$.

$S D S$ gel electrophoresis. All optic nerve samples were frozen at $-80^{\circ} \mathrm{C}$ immediately after removal from the animal. The $3-\mathrm{mm}$ segments from the first series of experiments (Fig. 1a) were homogenized in $90 \mu \mathrm{l} \mathrm{sample}$ huffer; the 2-mm segments from the second series of experiments (Fig. 1b) were homogenized in $60 \mu \mathrm{l} \mathrm{sample} \mathrm{buffer} \mathrm{(McKerracher} \mathrm{et} \mathrm{al.,} \mathrm{1990).}$ Consecutive segments were loaded on $7.5 \%$ acrylamide gels; the gels were stained with Coomassie blue, then processed for fluorography and exposed on preflashed film (McKerracher et al., 1990).

The peak of tubulin or NF labeling could not be used to measure the rate of slow transport because, in most experiments, the bulk of these proteins had not yet entered the crushed optic nerve stump. The rate of slow transport was therefore calculated by determining the position of the front of labeling in the optic nerve. We selected the front of the $150 \mathrm{kDa}$ middle NF subunit (NF-M) because it comigrates with the other labeled NF subunits and with tubulin but is well separated from other labeled protein bands in the gels (see Fig. 4). Each lane of an autoradiograph was scanned with a laser densitometer (LKB, Sweden) to determine the integrated ontical density of NF-M along the optic nerve. The position of the front of the labeling was estimated as the distance from the eye where the NF-M concentration dropped to $10 \%$ of its highest value for that animal.

RITC anterograde labeling of $R G C$ axons in the optic nerve. Axons remaining in the ocular stump of the optic nerve were visualized with the anterograde tracer rhodamine isothiocyanate (RITC) (Thanos et al., 1987). The optic nerve was crushed intracranially as above, and $6 \mathrm{~d}$ later, a solution of $2.5 \%$ RITC (mixed isomer, Sigma) and $2 \%$ dimethylsulfoxide was injected intravitrally $(n=5)$. RITC was also injected into the eye of unoperated control animals at the same time $(n=4)$. Five days later, the rats were perfused with saline, followed by $4 \%$ paraformaldehyde in $0.1 \mathrm{M}$ phosphate buffer $(\mathrm{pH} \mathrm{7.4)}$. Therefore, the optic nerves were examined at $11 \mathrm{~d}$ after crushing. Serial horizontal cryostat sections $15 \mu \mathrm{m}$ thick were mounted on coated slides and observed with epifluorescence (McKerracher et al., 1989).

Fast axonal transport of proteins. Optic nerves were crushed intracranially 1 month before the experiment. The RGCs of axotomized ( $n$ $=3$ ) and control $(n=4)$ rats were labeled with $250 \mu \mathrm{Ci}^{35} \mathrm{~S}$-methionine for $3 \mathrm{hr}$. The rats were killed, and 2-mm optic nerve segments were processed for SDS gel electrophoresis as described above, except that $9 \%$ acrylamide was used.

\section{Results}

\section{Slow axonal transport after optic nerve crush}

Tubulin $(55 \mathrm{kDa})$ and the NF triplet polypeptides $(68 \mathrm{kDa}, 150$ $\mathrm{kDa}$, and $200 \mathrm{kDa}$ ) are major cytoskeletal proteins that are transported in normal adult rat $\mathrm{RGC}$ axons at an approximate rate of $0.5 \mathrm{~mm} / \mathrm{d}$ (McQuarrie et al., 1986; McKerracher et al., a
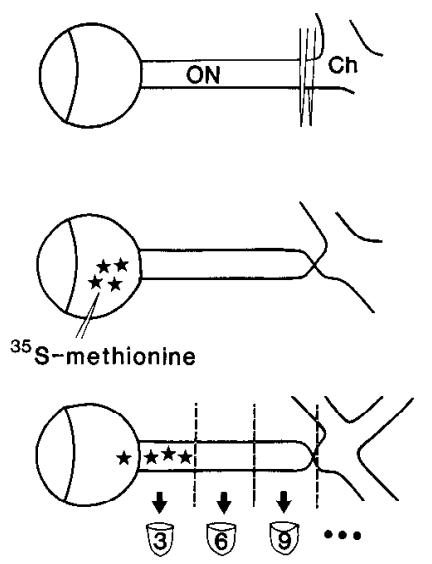

b
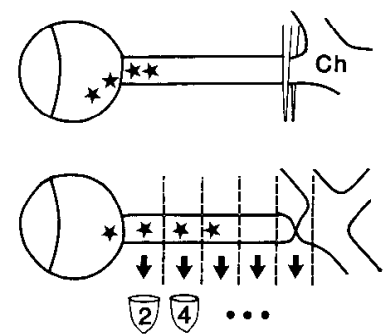

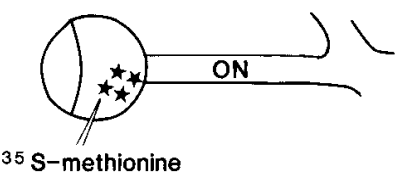

Figure 1. Illustration of the 2 experimental paradigms used to study the effect of axonal transection on slow transport. $a$, The optic nerve $(O N)$ was crushed with fine forceps approximately $9 \mathrm{~mm}$ from the eye near the optic chiasma $(C h)$. Seven d later, the RGC cell bodies within the eye were labeled by an intraocular injection of ${ }^{35} \mathrm{~S}-\mathrm{methionine.} \mathrm{Seven}$ to $60 \mathrm{~d}$ after labeling, the optic nerve stump was removed and cut into consecutive $3-\mathrm{mm}$ segments, and each segment was analyzed by SDS PAGE. $b$, The axonal proteins were prelabeled by an intraocular injection of ${ }^{35} \mathrm{~S}$-methionine. Six d later, when tubulin and NF proteins had just entered the proximal optic nerve (see Fig. 3), the optic nerve was crushed adjacent to the chiasma. Four to $60 \mathrm{~d}$ later, the optic nerve was removed and cut into $2-\mathrm{mm}$ segments, which were then processed for SDS PAGE.

1990). In the present studies of slow transport, the normal profile of cytoskeletal protein transport was altered following injury of the optic nerve. When the RGCs were labeled $7 \mathrm{~d}$ after the optic nerve was crushed (Fig. $1 a ; n=10$ ), both NF and tubulin labeling appeared to be reduced in relation to other labeled bands (Fig. 2). Furthermore, little or no NF protein was observed past the first $3 \mathrm{~mm}$ of the ocular stump of the optic nerve in the first $23 \mathrm{~d}$ after crushing (16 d after labeling; Fig. $2 a$ ), and NFs were not present further than $6 \mathrm{~mm}$ from the eye by $37 \mathrm{~d}$ after axotomy (Fig. $2 b$ ). While NF synthesis is known to decrease after injury (Hoffman and Cleveland, 1988; Tetzlaff et al., 1988), the total level of tubulin synthesis typically increases (Hoffman and Cleveland, 1988; Tetzlaff et al., 1988; Miller et al., 1989). It was therefore decided to investigate whether such a decrease in tubulin and NF labeling reflected a reduced axonal transport.

\section{Slow transport of prelabeled proteins after optic nerve crush}

To ascertain whether the slow transport rate of cytoskeletal proteins was altered by injury of RGC axons, we prelabeled these proteins in RGCs prior to crushing the optic nerve to determine whether previously synthesized polypeptides already within axons in the ocular stump of the optic nerve continued to migrate distally (Fig. $1 b$ ). For this purpose, the optic nerve was crushed $6 \mathrm{~d}$ after the intraocular injection of the radiolabel, which allowed enough time for tubulin and NFs to be transported along the first $2 \mathrm{~mm}$ of the optic nerve (Fig. 3 ).

The results of these experiments are shown in Figure 4. Four days after axotomy, the location of the labeled proteins was the same as in the contralateral uninjured optic nerves (Fig. 4a) However, at later time points, the front of labeled tubulin and NFs did not move at the same rate as the unoperated controls. Eight days after axotomy, the labcled tubulin and NF proteins were located $8-10 \mathrm{~mm}$ from the eye in the intact optic nerves 

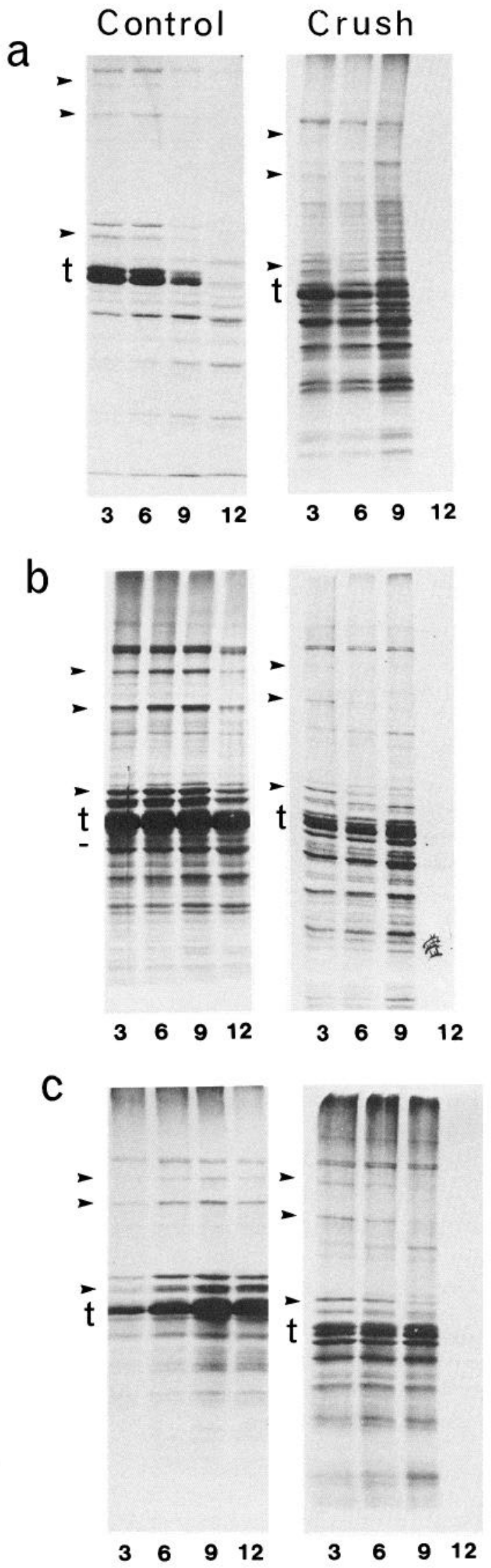

Figure 2. Slow transport in optic nerves labeled 1 week after the optic nerve was crushed. Consecutive 3-mm segments of control (left) and

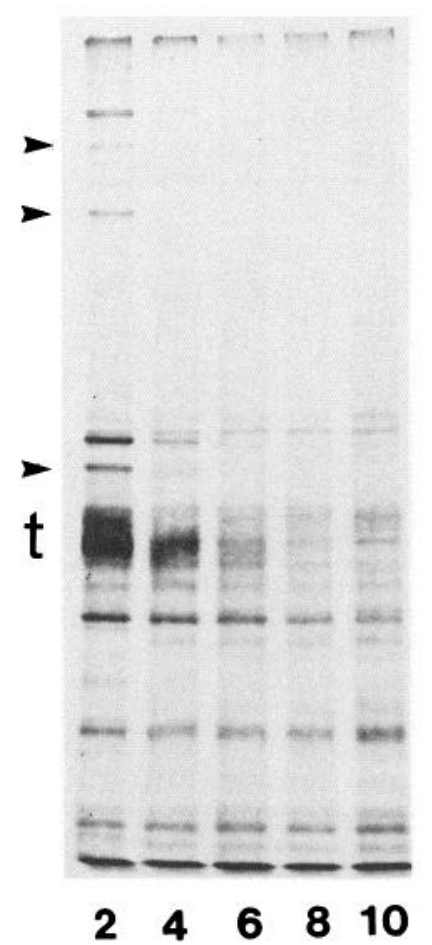

Figure 3. Consecutive 2-mm segments of an optic nerve processed 6 $\mathrm{d}$ after labeling. This fluorograph shows that the prelabeled tubulin and NF proteins (see Fig. $1 b$ ) have entered the first few $\mathrm{mm}$ of the optic nerve at the time when the optic nerve is crushed for the experiments shown in Figure 4.

but had not progressed beyond $6 \mathrm{~mm}$ in the ocular stump of the crushed optic nerves (Fig. $4 b$ ). Eleven days after axotomy, the labeled tubulin and NF had migrated $10 \mathrm{~mm}$ from the eye in the intact optic nerves but had not extended farther than 6 $\mathrm{mm}$ from the eye in the crushed optic nerves (Fig. $4 c$ ). Thirty days after axotomy, the tubulin and NF labeling had not reached the tip of the ocular stump of the optic nerve, whereas in the control optic nerves, the front of the labeled proteins had moved into the optic tract. (Fig. $4 d$ ).

\section{Tubulin and NF protein do not accumulate at the site of the crush}

When the optic nerve was prelabeled for a longer period of time (20 d), the peak of labeling, as indicated by the most intensely labeled bands (Fig. 5c), did not progress as far distally as in the unoperated controls by $10 \mathrm{~d}$ after crushing (Fig. 5). Therefore, the rate of tubulin and NF transport was decreased after injury, and tubulin and NFs did not accumulate at the site of the crush. In contrast, a more rapidly moving protein of $170 \mathrm{kDa}$, probably clathrin (McQuarrie et al., 1986), appeared to have accumulated at the site of injury (Fig. $4 c, d$ ).

The fronts of tubulin and NF labeling were consistently parallel after axotomy, indicating that the slow transport of both

crushed (right) optic nerves at $16(a), 30(b)$, and $60(c) d$ after labeling and 23,37 , and $67 \mathrm{~d}$ after crushing, respectively. The samples were treated as shown in Figure $1 a$, each fluorograph representing proteins in the optic nerve of a single animal. The segment of the optic nerve $12 \mathrm{~mm}$ from the eye is unlabeled in the crushed optic nerves, demonstrating that the injury completely interrupted the axons. The $3 \mathrm{NF}$ subunits (arrowheads) and tubulin $(t)$ are indicated. 


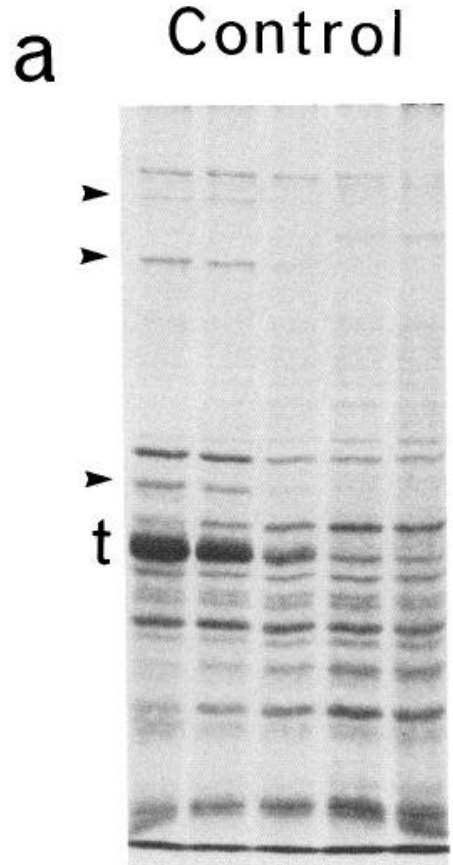

$\begin{array}{lllll}2 & 4 & 6 & 8 & 10\end{array}$

C

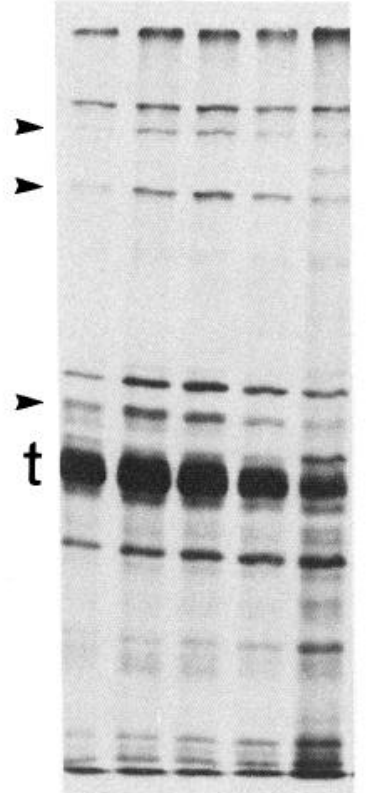

$\begin{array}{lllll}2 & 4 & 6 & 8 & 10\end{array}$
Crush

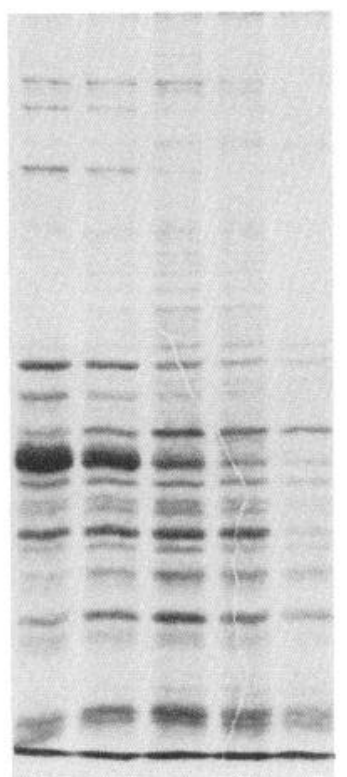

$\begin{array}{lllll}2 & 4 & 6 & 8 & 10\end{array}$

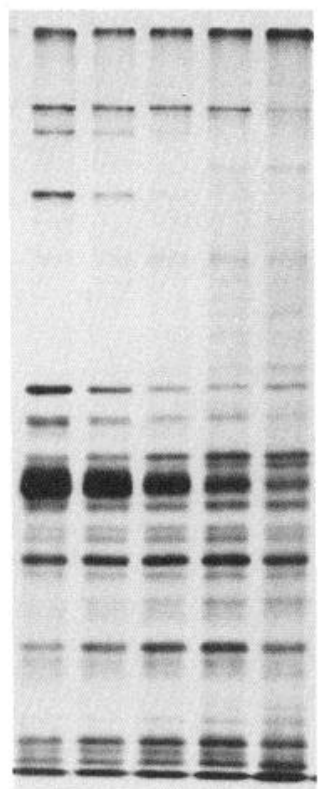

$\begin{array}{lllll}2 & 4 & 6 & 8 & 10\end{array}$ b

Control

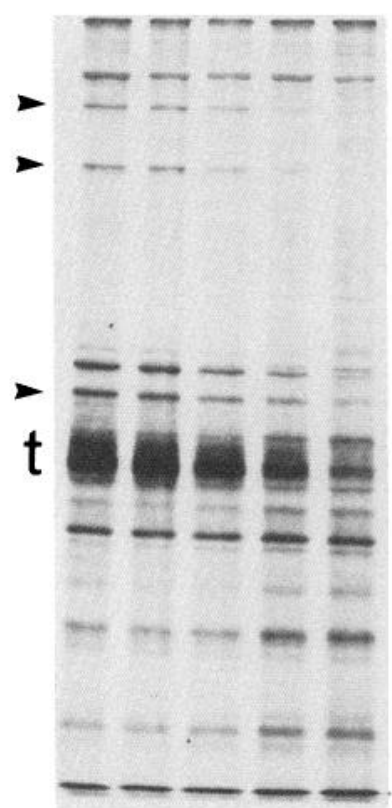

$\begin{array}{lllll}2 & 4 & 6 & 8 & 10\end{array}$

d

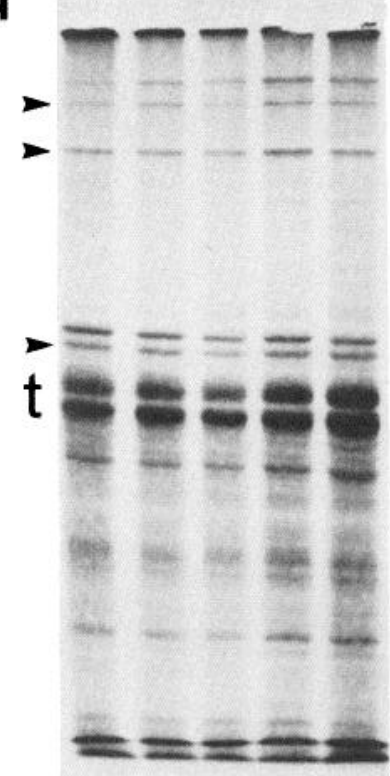

$\begin{array}{lllll}2 & 4 & 6 & 8 & 10\end{array}$
Crush

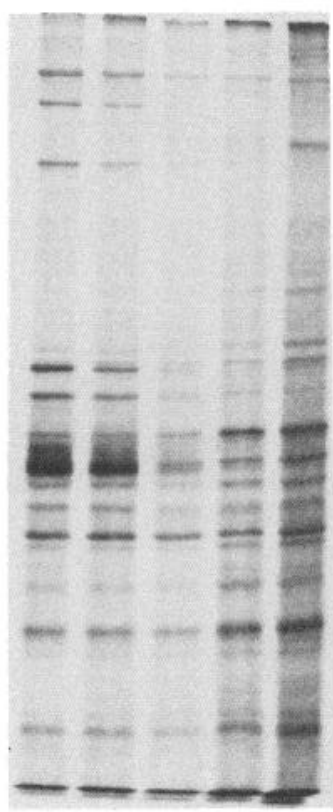

$\begin{array}{lllll}2 & 4 & 6 & 8 & 10\end{array}$

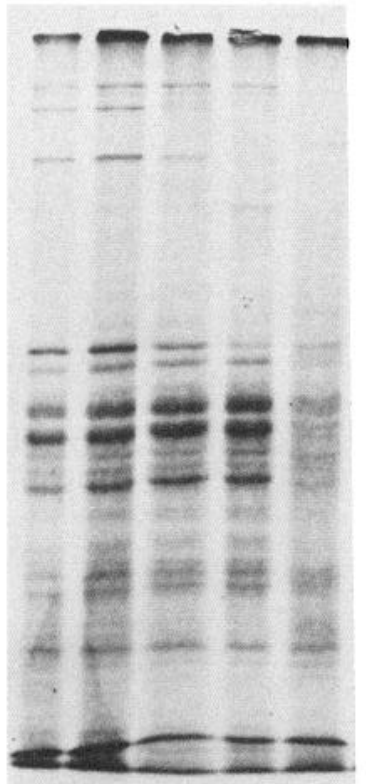

$\begin{array}{lllll}2 & 4 & 6 & 8 & 10\end{array}$

Figure 4. Fluorographs of slow transport in 2-mm segments of normal and contralateral crushed optic nerves after prelabeling (see Fig. 1 b). $a$, Four d after crushing, the tubulin $(t)$ and NF (arrowheads) labeling is similar in both control $($ left) and crushed (right) optic nerves. At $8(b)$ and $11(c) \mathrm{d}$ after the optic nerve crush, the front of tubulin and NF labeling does not move as far distally as in the unoperated controls. $d$, Thirty $\mathrm{d}$ after crushing (right), the labeled tubulin and NF proteins are near the site of the crush, $9 \mathrm{~mm}$ from the eye. In the control optic nerves (left), the slowly transported proteins have passed the end of the optic nerve and extend along the optic tract towards the tectum (see Fig. 5).

of these proteins was equally affected (Fig. 4). A visual examination of the labeling in paired crushed and contralateral control nerves revealed that the decrease in transport rate was first detectable $6 \mathrm{~d}$ after crushing. Measurements of transport rates from control and crushed nerves 4 and $6 \mathrm{~d}$ after crushing (10 and $12 \mathrm{~d}$ after injection, respectively; Fig. 6) also suggested a 1 week lag before the transport rate decreased following axotomy. However, at 30 and $60 \mathrm{~d}$ after crushing, there was some progression of axonally transported tubulin and NF in the ocular stump (Table 1). A regression analysis over the entire study period (Fig. 6) revealed that the rate of slow transport declined approximately 10 -fold, from $0.5 \mathrm{~mm} / \mathrm{d}$ to $0.06 \mathrm{~mm} / \mathrm{d}$. This 
a

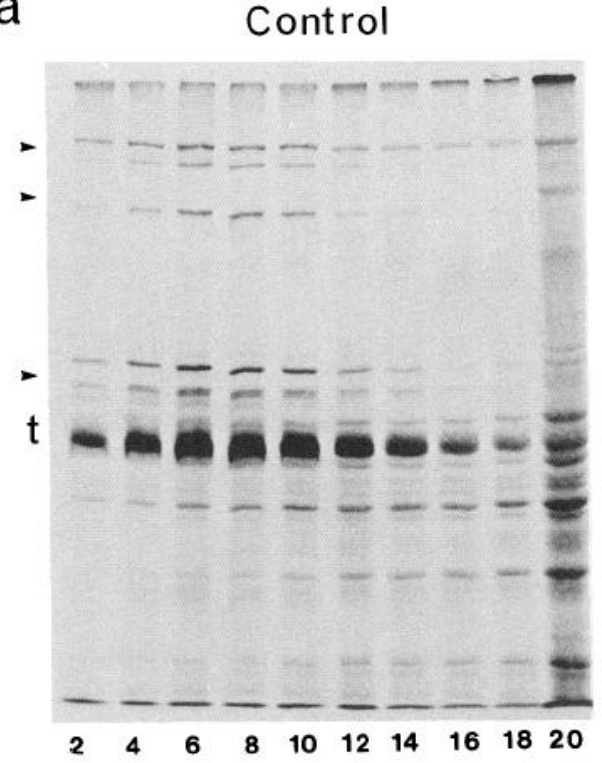

b

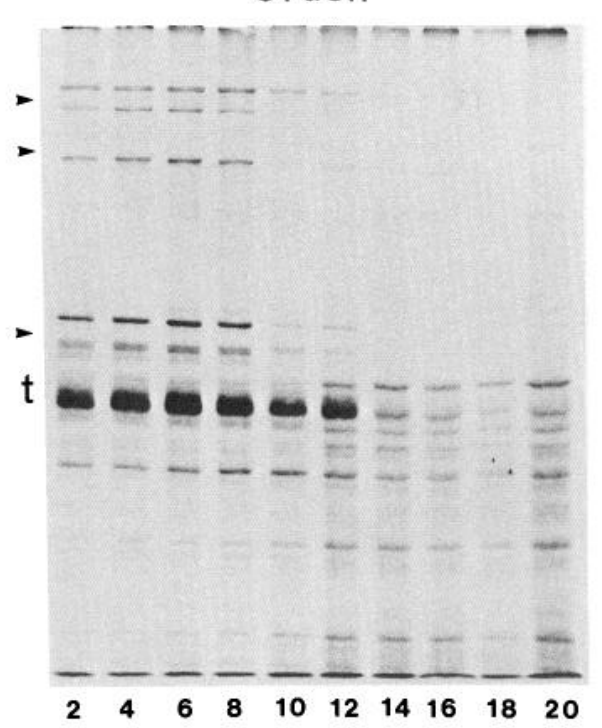

C

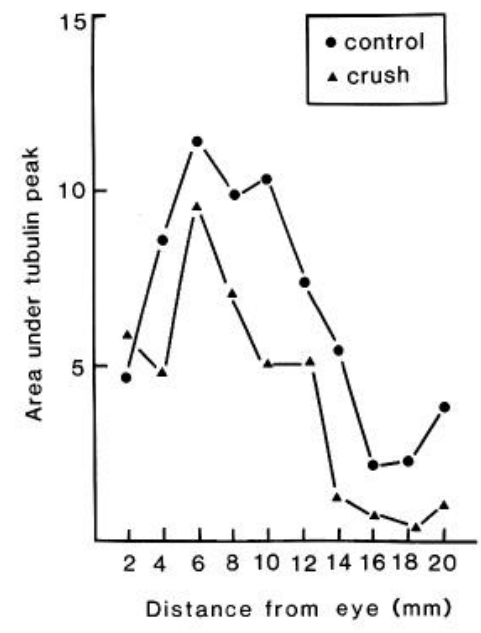

Figure 5. Delayed transport of tubulin and NF after optic nerve crush. The optic nerve was prelabeled for $20 \mathrm{~d}$ to allow the peak of tubulin and NF proteins to enter the optic nerve, and subsequently, the left optic nerve was crushed. Ten d later, the nerves were cut in 2 -mm segments and processed for fluorography $(a, b)$. The fluorograph was scanned with a laser densitometer to determine the relative concentration of tubulin at the different distances from the eye $(c)$. The delay in the rate of slow transport becomes apparent approximately 1 week after crushing.

change was a statistically significant $(p<0.001)$ decrease from the normal rate of axonal transport of these proteins.

\section{Survival of RGC axons in the ocular stump of the crushed optic nerve}

As in other regions of the CNS, many RGCs die soon after axotomy, and the number of cells that are lost increases gradually with time (Allcutt et al., 1984; Misantone et al., 1984; Villegas-Pérez et al., 1988, 1989; Sievers et al., 1989). Therefore, one possible explanation for our findings is that the alterations in NF and tubulin transport reflect a decline in the number of axons within the ocular stump of the injured optic nerve. To

\section{Table 1. Effect of optic nerve injury on slow transport}

\begin{tabular}{|c|c|c|c|c|c|}
\hline \multirow{2}{*}{$\begin{array}{l}\text { Days } \\
\text { between } \\
\text { labeling } \\
\text { and optic } \\
\text { nerve } \\
\text { crush }\end{array}$} & \multirow{2}{*}{$\begin{array}{l}\text { Total } \\
\text { number of } \\
\text { d after } \\
\text { labeling }\end{array}$} & \multirow{2}{*}{$\begin{array}{l}\text { Total } \\
\text { number of } \\
\mathrm{d} \text { after } \\
\text { crushing }\end{array}$} & \multicolumn{3}{|c|}{$\begin{array}{l}\text { Front of neurofilament } \\
\text { labeling }(\mathrm{mm})^{a}\end{array}$} \\
\hline & & & Normal & Crushed & $n$ \\
\hline 1 & 10 & 9 & 5 & 4 & 2 \\
\hline 6 & 10 & 4 & 7 & 6 & 3 \\
\hline 6 & 12 & 6 & 7 & 6 & 3 \\
\hline 6 & 14 & 8 & 9 & 6 & 5 \\
\hline 6 & 17 & 11 & 10 & 5 & 2 \\
\hline 6 & 36 & 30 & $\geq 10^{b}$ & 8 & 2 \\
\hline 6 & 66 & 60 & $\geq 10^{b}$ & 9 & 3 \\
\hline
\end{tabular}

${ }^{a}$ The front of NF transport for each animal was obtained densitometrically from autoradiographs similar to those shown in Figure 4. The transport front was estimated as the distance from the eye where NF-M labeling dropped to $10 \%$ of its maximum value; $n$ is the number of animals examined.

${ }^{b}$ In these experiments, only the optic nerve was examined. In other experiments (McKerracher et al., 1990), we found that by $30 \mathrm{~d}$, the transport front had reached the end of the axons approximately $20 \mathrm{~mm}$ from the eye. address this issue, we have used 2 different approaches: (1) a direct histological visualization of the axons remaining in the injured optic nerve, and (2) an analysis of RGC proteins transported in these nerves by fast axonal transport.

Longitudinal sections of the optic nerve prepared after the intravitreal injection of the fluorescent anterograde tracer RITC demonstrated the persistence of many RGC axons within the ocular stump of the injured optic nerve. While RITC labeling does not permit accurate estimates of axonal populations, the intensity of labeling, albeit reduced from controls, indicated the persistence of a large population of axons $11 \mathrm{~d}$ after crushing, a time when the changes in tubulin and NF transport were already overt (Fig. 7).

To verify further that enough axons were present in the optic nerve to permit the detection of axonal proteins near the site of the crush, we investigated the presence of the most rapidly migrating proteins $30 \mathrm{~d}$ after injury. Other studies have shown that fast transport continues in the ocular stump of the RGC axons after an intracranial interruption of the optic nerve (Skene and Willard, 1981) and that the major fast-transported protein labeled by ${ }^{35} \mathrm{~S}$-methionine is a neuron-specific protein (Lozano, 1988 ) of $28 \mathrm{kDa}$. We observed the appearance of this protein in both unoperated ( $n=4$ animals) and crushed $(n=3)$ optic nerves (Fig. 8). Therefore, certain axonal proteins continued to be transported to the site of crushing for at least $30 \mathrm{~d}$ after injury, and fast anterograde transport was not noticeably impaired by injury at a time when alterations in slow transport were apparent.

\section{Discussion}

\section{Rates of slow transport decrease after injury of $R G C$ axons}

The overall results of this study indicate that some of the main cytoskeletal proteins are not transported normally along the ocular stump of axotomized RGCs. The transport rate of NF and tubulin was markedly decreased after optic nerve crush, 


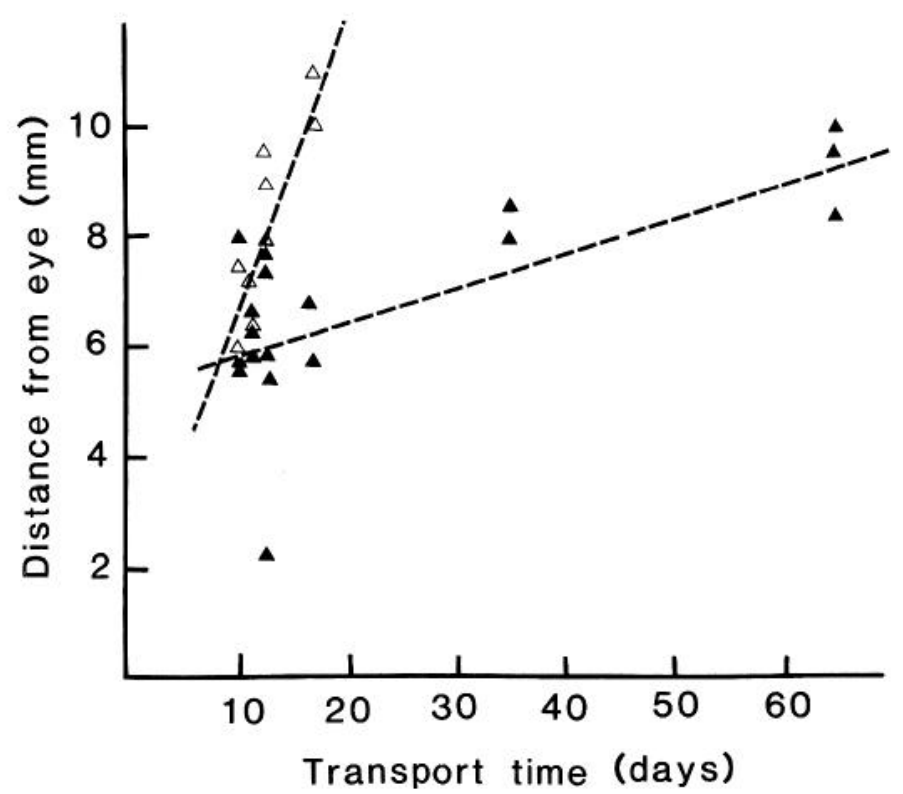

Figure 6. Regression analysis of slow transport rates. The transport front was determined densitometrically for the $150 \mathrm{kDa}$ NF-M in control (open triangles) and crushed (solid triangles) optic nerves. The relative concentrations of labeled NF-M in each lane were estimated from the integrated optical density, and the front of labeling was taken to be the distance from the eye where the concentration of NF-M dropped to $10 \%$ of the maximum value. The slope of the control regression line was 0.5 (correlation coefficient, 0.8 ) compared to 0.06 (correlation coefficient, 0.7) after optic nerve crush. The difference in the regression lines was significant $(p<0.001)$. The data at the 2 earliest time points suggest that there is an initial delay before the rate decrease.

the first change being detected approximately 1 week after injury.

These alterations in slow transport represent previously unrecognized neuronal responses to axotomy and may relate to the progressive degeneration of RGCs that follows the interruption of the optic nerve in mammals (Allcutt et al., 1984; Misantone et al., 1984; Villegas-Pérez et al., 1988, 1989; Sievers et al., 1989). The alteration in the transport of tubulin and NFs cannot be merely the result of a technical failure to detect labeling in optic nerves whose axonal population is reduced by the retrograde degeneration of the injured axons and RGCs
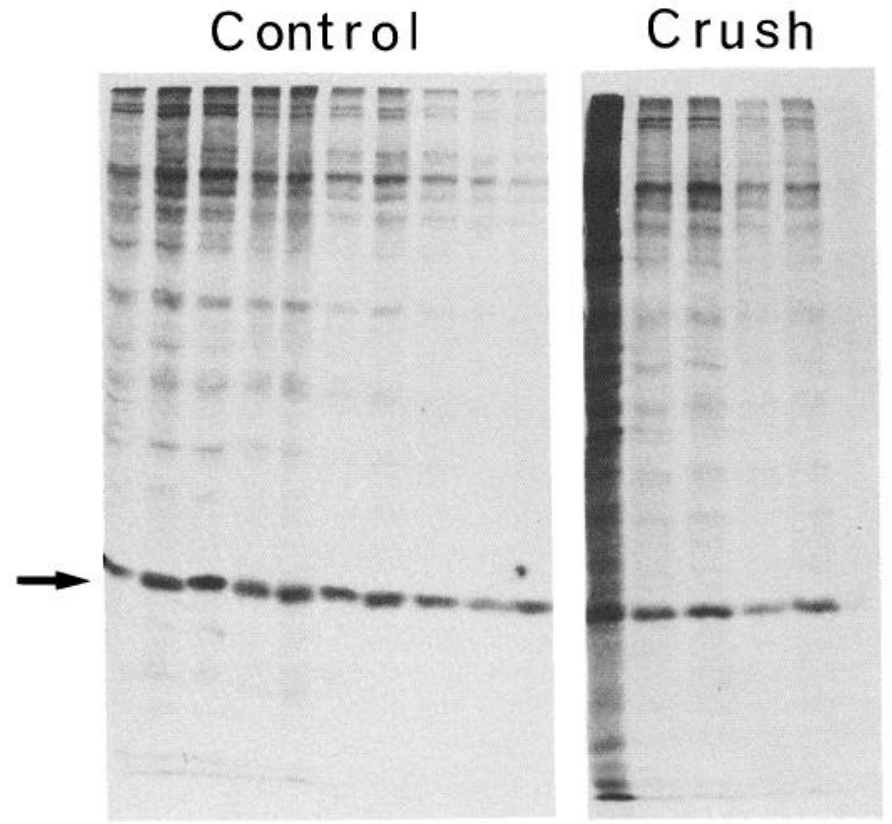

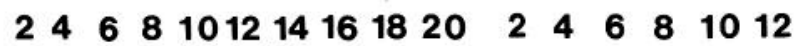

Figure 8. Fluorographs of fast anterograde transport in 2-mm segments of a normal optic nerve and tract (left) are compared with those of an optic nerve that was crushed $30 \mathrm{~d}$ previously (right). The major band is a $28 \mathrm{kDa}$ protein (arrow) that is clearly visible in all proximal segments of the crushed nerve (lanes 2-10). The presence of this and other bands confirms that many axons remain capable of sustaining fast transport after injury. The segments in the optic tract past the site of crushing remain unlabeled (lane 12). Approximate exposure times were 1 and 3 weeks, respectively.

(Grafstein and Ingoglia, 1982; Richardson et al., 1982; Giftochristos and David, 1988; Villegas-Pérez et al., 1988). This assertion is based on the following findings: (1) At the time when key observations on protein transport were made, many axons were proven anatomically by RITC labeling to extend along the entire optic nerve stump as far as the site of the injury (Fig. 7). (2) In previous experiments in adult rats where similar studies of slow transport were carried out during the regeneration of RGC axons into peripheral nerve grafts, we were able to detect the presence of tubulin, NFs, and other cytoskeletal proteins in axonal populations that averaged as few as 3600 axons, a num-

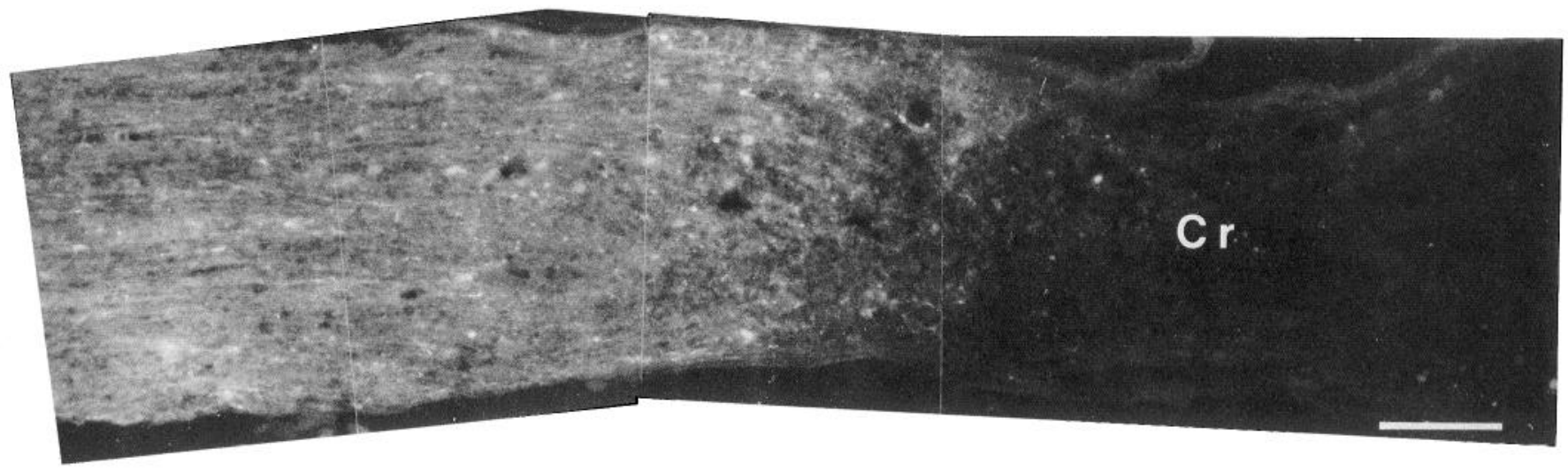

Figure 7. A longitudinal section of an optic nerve that was crushed intracranially. Six d after crushing, the axonal projection was labeled with RITC for a further $5 \mathrm{~d}$. Many fluorescent axons extend to the site of the crush $(\mathrm{Cr})$ but are absent past the site of the crush. Scale bar, $100 \mu \mathrm{m}$. 
ber that approximates $3 \%$ of the axons normally found in the optic nerve of rats (Vidal-Sanz et al., 1987; McKerracher et al., 1990). Our detection of such proteins and the measurement of their transport rates in such experiments are an indication of the sensitivity of the methods we have used. (3) Neuronal proteins conveyed by fast axonal transport were observed in the ocular stump of the optic nerve for at least $30 \mathrm{~d}$ after axotomy (Fig. 8). Typically, the fast-transported proteins are less heavily labeled than the slowly transported proteins (Levine and Willard, 1980). (4) The presence of labeled tubulin and NF at the level of the optic chiasma with a 20 -d prelabeling time (Fig. 5) shows that cytoskeletal proteins already transported along RGC axons can be detected for at least $10 \mathrm{~d}$ after injury, a time when the alterations in slow transport were already marked. (5) While we cannot exclude the possibility that subpopulations of RGCs may transport proteins at different rates, and that axotomy predominantly affects those RGCs that transport tubulin and NFs faster, such an explanation is unlikely: in the rat optic nerve, the peak and front of tubulin and NF transport move at the same rate (McQuarrie et al., 1986; McKerracher et al., 1990), a finding that suggests that all RGC axons transport proteins at similar and uniform speeds.

\section{Slow transport decreases in response to axotomy in the optic} nerve

The results presented here are in contrast to the enhancement of slow transport observed in regenerating axons of the peripheral nervous system. After injury to peripheral nerves, tubulin synthesis increases, while NF synthesis decreases (Hoffman and Cleveland, 1988; Tetzlaff et al., 1988). The expression of a developmentally regulated gene for tubulin and the overall level of tubulin message is higher in such injured nerves (Hoffman and Cleveland, 1988; Miller et al., 1989). While the rate of tubulin transport increases during regeneration of many different classes of neurons (Hoffman et al., 1985; Grafstein, 1986), including those of regenerating rat RGCs (McKerracher et al., 1990), we report here that RGCs injured in the optic nerve show a marked decrease in the rate of slow transport of tubulin. Changes in tubulin transport may alter the normal equilibrium between synthesis, microtubule assembly, and the migration of microtubules out of the cell soma, thereby affecting the tubulin subunit pool. The interruption of RGC axons may therefore interfere with tubulin expression by affecting its posttranscriptional autoregulation (Pittenger and Cleveland, 1985). However, we do not know whether the failure of slow transport is followed by any changes in tubulin synthesis, or alternately, whether it may bc a consequence of altered tubulin gene expression.

Several lines of evidence suggest that decreases in slow transport can accompany certain types of injury to central and peripheral neurons. These include the immunocytochemical detection of an accumulation of phosphorylated NF epitopes within the soma of injured RGCs (Drager and Hofbauer, 1984; VidalSanz et al., 1987) and the ultrastructural observation of increased NFs within some axotomized RGCs (Barron el al., 1986). The autoradiographic finding of reduced labeling in longitudinal sections of injured optic nerves from squirrel monkeys also suggests that a decrease in slow transport follows RGC axotomy in primates (Quigley et al., 1977). Furthermore, a lag in the migration of labeled NFs and tubulin has been described in the central branch of the dorsal root ganglion cells after sciatic nerve section (Oblinger and Lasek, 1988). Finally, certain neurotoxic agents such as aluminum cause a decrease in the rate of slow transport in peripheral nerves (Bizzi et al., 1984; Troncoso et al., 1985).

\section{Degeneration of $R G C$ axons and neurons after intracranial crushing of the optic nerve}

After axotomy, the pace of cell loss in the retina is influenced by the distance that separates the lesion and the cell body (Villegas-Pérez et al., 1989). When the optic nerve is crushed near the optic chiasma, as in the experiments reported here, approximately $70 \%$ of the RGCs survive 1 month, but by 6 months, the RGC population is only $40 \%$ of normal (Villegas-Pérez et al., 1989, unpublished observations). Thus, a protracted loss of RGCs follows intracranial axotomy in the optic nerve of adult rats. Axonal degeneration likely precedes such protracted cell loss because optic nerve axons (Richardson et al., 1982) are lost in greater numbers than RGCs. The existence of a relationship between the described failure of cytoskeletal protein transport and such progressive degeneration of axons and neurons is a possibility that warrants further investigation.

\section{Differences between injured and regenerating $R G C s$}

We do not know why slow transport is decreased after RGC axotomy rather than enhanced, as in the peripheral nervous system. This observation is even more puzzling because we have previously shown that the transport rates of tubulin and NF double when the severed $\mathrm{RGC}$ axons regenerate along a peripheral nerve graft (McKerracher et al., 1990). While our results suggest that the transport of cytoskeletal proteins is different, depending on whether or not injured RGCs regenerate their axons, it should be noted that the peripheral nerve grafts were anastomosed to the optic nerve cut immediately behind the eye, whereas in the present experiments, RGC axons were intracranially interrupted.

It is interesting that the effect of axotomy on slow transport was first apparent 1 week after injury, because RGC axons exhibit a short-lasting sprouting response after they are interrupted in the optic nerve. The number of sprouts formed at the tip of the ocular stump appears to decline several weeks after transection (Ramón y Cajal, 1928; Richardson et al., 1982). It has also been reported that the ability of RGCs to regrow transected axons into peripheral nerve grafts drops approximately $7 \mathrm{~d}$ after injury (Thanos and Vanselow, 1989). Possibly, the deficit in slow transport that develops 1 week after injury represents a transition to a state where the axotomized RGCs fail to sustain axonal regrowth within the optic nerve. Such axonal elongation may require appropriate interactions with permissive and trophic components in the external milieu. It remains to be determined in other CNS and PNS neurons whether a similar decrease in slow transport is an indicator of a nerve cell response to axonal injury under conditions that do not promote axonal elongation.

\section{References}

Allcutt D, Berry M, Sievcrs J (1984) A quantitative comparison of the reactions of retinal ganglion cells to optic nerve crush in neonatal and adult mice. Dev Brain Res 16:219-230.

Barron KD, Dentinger MP, Krohel G, Easton SK, Mankes R (1986) Qualitative and quantitative ultrastructural observations on retinal ganglion cell layer of rat after intraorbital optic nerve crush. J Neurocytol 15:345-362.

Bizzi A, Crane RC, Autilo-Gambetti L, Gambetti P (1984) Aluminum effect on slow axonal transport: a novel impairment of neurofilament transport. J Neurosci 4:722-731.

Carter DA, Bray GM, Aguayo AJ (1989) Regenerated retinal ganglion 
cell axons can form well-differentiated synapses in the superior colliculus of adult hamsters. J Neurosci 9:4042-4050.

Drager U, Hofbauer A (1984) Antibodies to heavy neurofilament subunit detect a subpopulation of damaged ganglion cells in retina. Nature 309:624-626.

Giftochristos N, David S (1988) Laminin and heparan sulfate proteoglycan in the lesioned adult mammalian central nervous system and their possible relationship to axonal sprouting. J Neurocytol 17: 385-397.

Grafstein B (1986) The retina as a regenerating organ. In: The retina (Adler R, Farber D, eds), pp 275-335. New York: Academic.

Grafstein B, Ingoglia NA (1982) Intracranial transection of the optic nerve in adult mice: preliminary observations. Exp Neurol 76:318330.

Hoffman P, Cleveland DW (1988) Neurofilament and tubulin expression recapitulates the developmental program during axonal regeneration. Proc Natl Acad Sci USA 85:4530-4533.

Hoffman PN, Thompson GW, Griffin JW, Price DL (1985) Changes in neurofilament transport coincide temporally with alterations in the caliber of axons in regenerating motor fibers. J Cell Biol 101:13321340 .

Keirstead SA, Rasminsky M, Fukuda Y, Carter DA, Aguayo AJ, VidalSanz M (1989) Electrophysiologic responses in hamster superior colliculus evoked by regenerating retinal axons. Science $246: 255-257$.

Levine J, Willard M (1980) The composition and organization of axonally transported proteins in the retinal ganglion cells of the guinea pig. Brain Res 194:137-154.

Lozano AM (1988) The expression of the growth associated protein GAP-43 in the injured and regenerating retinal ganglion cells of the adult rat. PhD Thesis, McGill University.

McKerracher L, Vallee RB, Aguayo AJ (1989) Microtubule-associated protein 1A (MAP 1A) is a ganglion cell marker in adult rat retina. Visual Neurosci 2:349-356.

McKerracher L, Vidal-Sanz M, Aguayo AJ (1990) Slow transport rates of cytoskeletal proteins change during regeneration of axotomized retinal neurons in adult rats. J Neurosci 10:641-648.

McQuarrie IG, Brady ST, Lasek RJ (1986) Diversity in the axonal transport of structural proteins: major differences between optic and spinal axons in the rat. J Neurosci 6:1593-1605.

Miller FD, Tetzlaff W, Bisby MA, Fawcett JW, Milner RJ (1989) Rapid induction of the major embryonic $\alpha$-tubulin mRNA, T $\alpha 1$, during nerve regeneration in adult rats. J Neurosci 9:1452-1463.

Misantone LJ, Gershenbaum M, Murry M (1984) Viability of retinal ganglion cells after optic nerve crush in adult rats. J Neurocytol 13: $449-465$.
Oblinger M, Lasek RJ (1988) Axotomy-induced alterations in the synthesis and transport of neurofilaments and microtubules in dorsal root ganglion cells. J Neurosci 8:1747-1758.

Pittenger MF, Cleveland DW (1985) Retention of autoregulatory control of tubulin synthesis in cytoplasts: demonstration of a cytoplasmic mechanism that regulates the level of tubulin expression. J Cell Biol 101:1941-1952.

Quigley HA, Davis EB, Anderson DR (1977) Descending optic nerve degeneration in primates. Invest Opthalmol Visual Sci 16:841-849.

Ramón y Cajal S (1982) Degeneration and regeneration of the nervous system (May RM, trans), pp 583-596. London: Oxford U P.

Richardson PM, Issa VMK, Shemie S (1982) Regeneration and retrograde degeneration of axons in the rat optic nerve. J Neurocytol 11: 949-966.

Sievers J, Hausman B, Berry M (1989) Fetal brain grafts rescue adult retinal ganglion cells from axotomy-induced cell death. J Comp Neurol 281:467-478.

Skene JHP, Willard M (1981) Axonally transported proteins associated with axon growth in rabbit central and peripheral nervous systems. J Cell Biol 89:96-103.

Tetzlaff W, Bisby MA, Kreutzberg GW (1988) Changes in cytoskeletal proteins in the rat facial nucleus following axotomy. J Neurosci 8 : $3181-3189$.

Thanos S, Vanselow J (1989) Adult retinal ganglion cells retain the ability to regenerate their axons up to several weeks after axotomy. J Neurosci Res 22:144-149.

Thanos S, Vidal-Sanz M, Aguayo AJ (1987) The use of rhodamineB-isothiocyanate (RITC) as an anterograde and retrograde tracer in the adult rat visual system. Brain Res 406:317-321.

Troncoso JC, Hoffman PN, Griffin JW, Hess-Kozlow KM, Price DL (1985) Aluminum intoxication: a disorder of neurofilament transport in motor neurons. Brain Res 342:172-175.

Vidat-Sanz M, Bray GM, Villegas-Pérez MP, Thanos S, Aguayo AJ (1987) Axonal regeneration and synapse formation in the superior colliculus by retinal ganglion cells in the adult rat. J Neurosci 7:28942909.

Villegas-Perez MP, Vidal-Sanz M, Bray GM, Aguayo AJ (1988) Influence of peripheral nerve grafts on the survival and regrowth of axotomized retinal ganglion cells in the adult rat. J Neurosci 8:265280.

Villegas-Perez MP, Vidal-Sanz M, Bray GM, Aguayo AJ (1989) The distance of axotomy from the neuronal cell body influences the rate of retrograde degeneration but not long-term survival of retinal ganglion cells (RGCs). Soc Neurosci Abstr 15:457. 